\title{
Using the Word Association Test to Examine Life Skills Cognitive Structures of Pre-Service Science Teachers
}

\author{
Merve Bahar Alaca ${ }^{*}$, Havva Yaman ${ }^{1}$, Sibel Er Nas ${ }^{1}$ \\ ${ }^{1}$ Matematik ve Fen Bilimleri Eğitimi Bölümü, Fatih Eğitim Fakültesi, Trabzon Üniversitesi, Turkey. \\ *Corresponding Author mervebaharalaca@hotmail.com
}

\begin{abstract}
Science teachers, while teaching their students the science concepts, should also be teaching life skills. To ensure that future science teachers are competent to teach these skills, it can help assess the cognitive structures they hold as pre-service teachers. The current study aimed to reveal the cognitive structures and conceptual knowledge status of pre-service science teachers related to life skills. The participants were 165 pre-service teachers studying at the Department of Elementary Science Education at a public university in Turkey. A word association test (WAT) using six keywords (Communication, teamwork, entrepreneurship, creativity, decision making, analytical thinking) about life skills was developed. The gathered data was analyzed with the interslice distance technique and a descriptive analysis method. The results suggest that pre-service science teachers do not have the cognitive structures to produce enough answer words about life skills. It is suggested that elective undergraduate courses that allow students to recognize and internalize these skills can be introduced or increased in pre-service teaching programs.
\end{abstract}

Keywords Pre-service teachers, Cognitive structure, Life skills, Word association test

\section{INTRODUCTION}

Our rapidly changing living conditions, depending on the advances in science and technology, face people with a wide variety of difficulties. How to deal with these difficult situations is one of the fundamental issues that specialists, especially educators. For this reason, life skills education is taken into consideration more and more throughout the world in the organization of educational systems (World Health Organization [WHO], 1999). The studies carried out for the education of life skills aim for individuals to develop in a personal, social, academic, professional, and moral sense (Kolburan \& Tosun, 2011). Life skills, which are very functional in terms of adaptation of the individual to the society, were included in the science curriculum in 2013 as field-specific skills (scientific process skills, life skills, engineering, and design skills). Life skills are expressed as basic skills in reaching and using scientific information in the science education curriculum (MoNE, 2018). Science Course Curriculum covers basic life skills such as "analytical thinking, decision making, creativity, entrepreneurship, communication and teamwork" related to accessing and using scientific information. Researches show that students associate science concepts with their daily life experiences, cannot use them directly (Burbules \& Linn, 1991; Stolk, Bulte, De-Jong \& Pilot, 2009). It is also difficult for an individual who cannot learn basic science concepts to find solutions to daily life problems. These individuals have difficulties producing different solutions and establishing logical relationships between concepts (Crespo \& Pozo, 2004; Gilbert, 2006). It is aimed to use life skills by associating them with objectives in the educational process and daily life problems and thus facilitating life (Erbil, et al., 2004). It is necessary to learn basic science concepts to gain and develop analytical thinking, creative thinking, entrepreneurship, and decision-making skills from life skills included in the Science Education Program's skill learning field. Because when searching for answers to daily life problems, students may need to think analytically or creatively or decide the correct way through different solutions. Namely, for a student to solve a problem in daily life, s/he must first determine the relationship of this problem with science concepts and then use life skills to solve the problem. Besides, students should have communication skills to work in harmony with their teammates and work in teamwork while looking for solutions to their problems (Kirman-Bilgin, 2019). It is the teachers who will bring these skills to the students. For this

Received: 15 June 2020

Revised: 25 November 2020

Published: 28 November 2020 
reason, it is important to provide pre-service teachers with these skills during their undergraduate education. However, the related literature does not provide any remarkable information draws attention to how the preservice teachers are familiar with these skills, what kind of activities they can gain for students, what kind of data collection tools they can use to measure these skills, how to interpret the scores obtained and how much professional knowledge they are equipped. The relevant researches emphasize that the curriculum needs to be updated to keep up with the changing world, but that the proficiency of professional knowledge of pre-service teachers is required to follow the process continuously (Abell, 2008; Kind, 2009; Nilsson, 2008; Padilla, PonceLeón, Rembado \& Garritz, 2008). Equipping pre-service teachers with professional knowledge and skills in line with the goals and objectives of the science curriculum is important for meeting the educational goals (Brown, Morehead \& Smith, 2008; Stronge \& Hindman, 2003) and increases the quality of education of the school they work at when they start their jobs (Ross, 1992; Stronge, Ward, Tucker \& Hindman, 2007). It will be difficult for preservice science teachers who do not know the life skills included in the curriculum and do not develop their skills, to improve students' life skills in the future (Alaca, 2019). Therefore, it is important to conduct research that allows pre-service science teachers to recognize their life skills and develop their life skills to achieve the desired learning outcomes for students' life skills. Science teachers, while teaching their students the concepts of science, should also improve their life skills. Pre-service teachers cannot receive education at the level of the criteria determined in their preservice period; they encounter many problems when they start their professional life (Baykara-Pehlivan, 2005). Therefore, pre-service teachers should acquire these skills. To ensure that future science teachers acquire these skills at the desired level, the pre-service teachers' cognitive structures must first be revealed. Determining how much pre-service science teachers are familiar with these skills will play a major role in selecting vocational courses and guiding the pedagogical content knowledge courses. There are minimal studies in the related literature on the awareness and use of pre-service science teachers' life skills. Simultaneously, it is thought that it will present an idea to the studies related to teacher training programs.

In this research, which aims to reveal the cognitive structures and conceptual knowledge status of pre-service science teachers for life skills, answers to the following questions were sought: How do life skills shape the preservice science teachers' cognitive structures? What are the conceptual knowledge statuses of pre-service science teachers regarding life skills?
Please write down what the "communication" word reminds you.

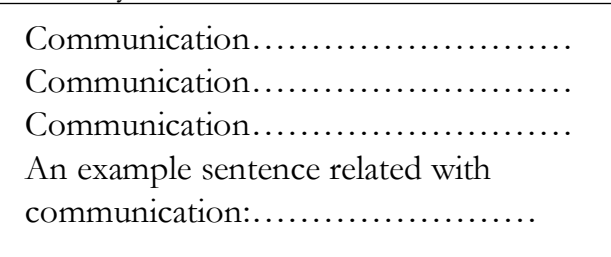

Figure 1 A sample WAT sheet format

\section{METHOD}

The research is descriptive in the survey model. Descriptive researches try to reveal the existing situation quantitatively or qualitatively. Descriptive researches aim to classify and describe behaviors according to their common characteristics (Simon \& Burstein, 1985). The survey model is the research approach that aims to describe the conditions in the past or a situation that is still ongoing without changing the conditions (Karasar, 2012).

\subsection{Sample}

The study sample consisted of 165 pre-service teachers studying at the Department of Elementary Science Education at a public university in Turkey. Twenty-seven of these students are first grade, 30 of the second grade, 64 of the third grade, and 44 fourth-grade students. The participants voluntarily participated in the research.

\subsection{Word Association Test (WAT)}

The WAT reveals the students' cognitive structures and inter-and Intralinks between them (Bahar, Johnstone \& Sutcliffe, 1999). The WAT was used as the data collection tool in the research. Six keywords (Communication, teamwork, entrepreneurship, creativity, decision making, analytical thinking) that form life skills were included to create the test. In practice, each concept is prepared with a page. Each life skills word was written on a separate sheet five times, one under the other. All WAT sheets had the same format in the current research. Figure 1 shows a sample WAT sheet format.

\subsection{Data Collection}

Before starting the application, the students were given explanations about applying the test, and examples were given about the application in different fields. Students were given one minute for each key concept. In the literature, it was observed that there were variations in the time given by the grade level in different studies. Kaya \& Taşdere (2016) in their work with 4th grade, 1 minute 30 seconds; Ercan, Taşdere, \& Ercan (2010), on the other hand, did a one-minute study with their 7th grade; In their studies with 8th-grade students in Inel, Akar \& Uztemur (2016), it was determined that 1-minute periods were given to the students to produce answer words. As this research was conducted for prospective teachers, it was deemed appropriate for 30 seconds. In the literature, it was observed that there were variations in the time given by the grade level in different studies. Kaya \& Taşdere (2016) gave 
1 minute 30 seconds in their work with 4th grade; Ercan, Taşdere, \& Ercan, (2010), on the other hand, found 1 minute sufficient for students in their research with 7 th grade; Inel, Akar \& Uztemur (2016), gave students 1 minute to produce answer words in their studies with their 8th-grade students. As this research was conducted for preservice science teachers, it was deemed appropriate for 30 seconds. The pre-service teachers wrote the answer words they thought about the critical concept during this given period. In the prepared WAT, each keyword is written one after the other on a single page. Otherwise, it is possible that the pre-service teacher, who filled the WAT, gave the previous words as an answer. This situation will damage the purpose and reliability of the test (Bahar \& Özatli, 2003). To ensure that pre-service teachers allocate equal time for each keyword in the test and the general order, another keyword was started after passing the time given for each word.

Pre-service teachers were asked to use the answer words for each keyword sentence in the relevant sentence section at the end of the form. This situation is to determine whether the teacher candidates know the keywords by the subject content or whether the answer is a superficial association product (Gürkan, 2019; Nartgün, 2006).

\subsection{Data Analysis}

In the WAT analysis process, the number of answer words produced by students is one of the methods used to evaluate the data. To evaluate the results, the answers given to the keywords were examined in detail. A frequency table has been created to show which words or concepts are repeated for which keyword. Because whether a keyword is understood depends on the number and quality of the words associated with that keyword (Bahar, Nartgün, Durmuş, \& Biçak, 2006). Based on the frequency table created, a concept network was drawn, demonstrating the cognitive structures of Science Education undergraduate students. While these maps were drawn, the breakpoint technique introduced by Bahar, Johnstone, \& Sutcliffe (1999) was applied. Accordingly, the answer given to any keyword in the frequency table is used as a breakpoint 3-5 unit below the word. The concepts and answer words above this frequency are associated with interconnection lines and drawn to the concept network's first part. Then, the breakpoint was pulled down at certain intervals, and the associations continued until all keywords and answer words appeared (Ercan, Taşdere, \& Ercan, 2010). The number in each breakpoint range shows how many pre-service teachers respond to the keywords. The emerging word numbers, the number of associations in concept networks, the suitability and quality of the associated words with the subject content were evaluated during the process of revealing the cognitive structure and conceptual change level. Besides, in the light of the content meanings and qualities of the participants' sentences, the analysis processes were terminated by making "scientifically correct sentences related to the concept", "sentences containing unscientific or superficial information", "sentences with misconception," and "intentionally left blank" classifications. If the sentences related to the concept are scientifically correct and related to the concept, they have discussed under the heading "sentences containing scientific information"; content sentences that are not scientifically correct and used in daily life, reflecting only their feelings and thoughts, and made meaningful with their past experiences and traditions were discussed under the heading "sentences containing non-scientific and superficial information". Lastly, sentences containing mixed expressions and concepts used with different and wrong meaning concepts or expressions were discussed under the heading "sentences with misconception". This category is not included in the tables since there were not any misconceptions in the sentences. The pre-service science teachers were coded in terms of research ethics. For example, the $10^{\text {th }}$ pre-service science teacher, 3rd grade, is coded as 3PT-10.

\section{RESULT AND DISCUSSION}

Findings obtained from the research are presented by using tables and figures. In the research, words with a frequency of 15 and above according to the breakpoints are shown in figures. The words under the concepts are presented with figures according to the breakpoints. Accordingly, the concept network created for breakpoint 90 and above is shown in Figure 2.

Breakpoint 90 and above: As shown in Figure 2, only the speaking word for the concept of Communication was produced by pre-service science teachers according to the specified breakpoint. It is seen that no words are produced for other concepts. Figure 3 shows the concept network created for breakpoint 75 and above. Breakpoint 75 and above: As seen in Figure 3, unlike the previous breakpoint, teamwork was also associated with the group word.

Breakpoint 60 and above: As seen in Figure 4, unlike the previous breakpoint, teamwork is associated with unity, entrepreneurship is associated with savings, creativity is

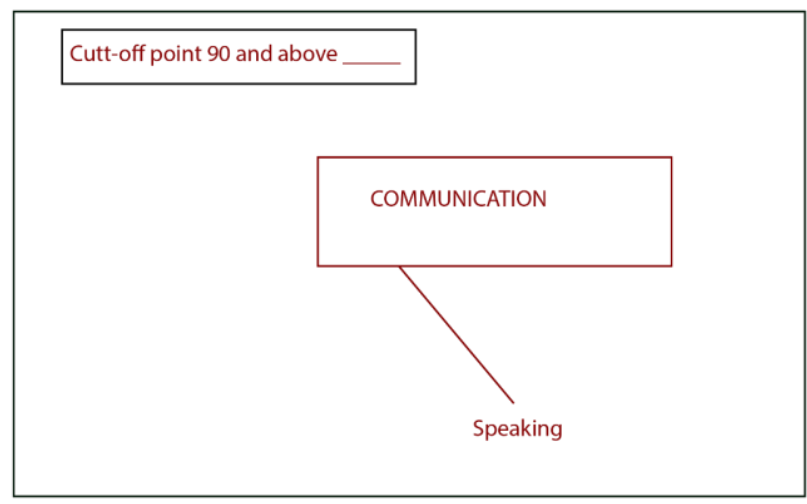

Figure 2 The concept network created for breakpoint 90 and above 


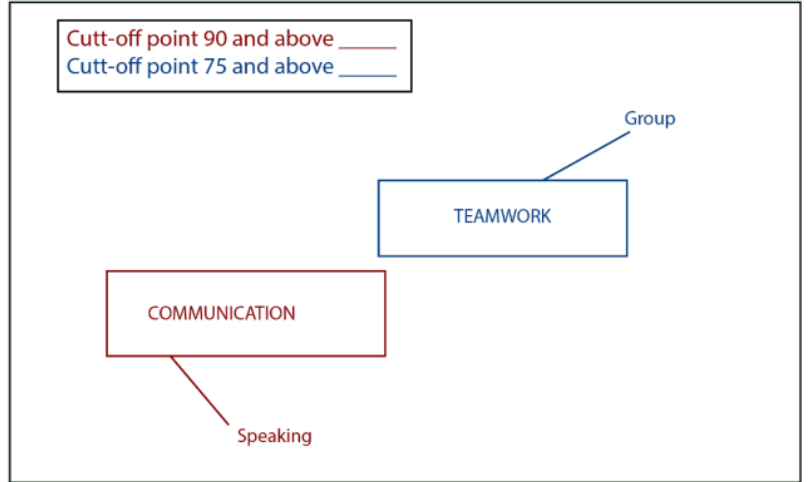

Figure 3 The concept network created for breakpoint 75 and above

associated with imagination, and decision making is associated with multidimensional perspectives.

Breakpoint 45 and above: As seen in Figure 5, unlike the previous breakpoint, the communication concept is associated with the words gesture and mimic and diction by teacher candidates. Besides, it is seen that the concept of entrepreneurship is associated with assertiveness, the concept of creativity is associated with authenticity, the concept of decision making is associated with choicemaking, and the concept of analytical thinking is associated with computational and mathematic words.

Breakpoint 30 and above: As seen in Figure 6, unlike the previous breakpoint, the concept of Communication is associated with language, listening, and human, the concept of entrepreneurship is associated with effective Communication, social environment, self-confidence and productivity, and the concept of teamwork is associated with the word solidarity. Also, it is seen that the concept of decision making is associated with the words outcome, commitment, and discriminating, the concept of creativity is associated with the words innovation, generating an idea, multidimensional perspectives, and intelligence, and the concept of analytical thinking is associated with the words reasoning, multidimensional perspectives, and intelligence. Moreover, the intelligence word is associated with the concept of both creativity and analytical thinking; on the other hand, the multidimensional perspectives word is associated with the concepts of decision making, analytical thinking, and creativity.

Breakpoint 15 and above: As seen in Figure 7, the whole concept network for pre-service science teachers' concepts of Communication, teamwork, entrepreneurship, creativity, decision making, and analytical thinking and the words they produce about them has emerged. Unlike the previous breakpoint, the concept of Communication is associated with the words sociability, telephone, eye contact, the style, respecting, conversation, agreement, expression of oneself, body language, the concept of teamwork is associated with the words friendship, project, division of labor, adjustment, and sense of responsibility and the concept of entrepreneurship is associated with the words profession, ability, and businessman. The different perspectives word has been associated with the concepts of both teamwork and creativity by pre-service teachers. Besides, it was seen that the concept of creativity was associated with the different perspectives, skills, standard product, designing, productivity, reasoning words, and the concept of analytical thinking was associated with creativity, science education, details, problem, abstract

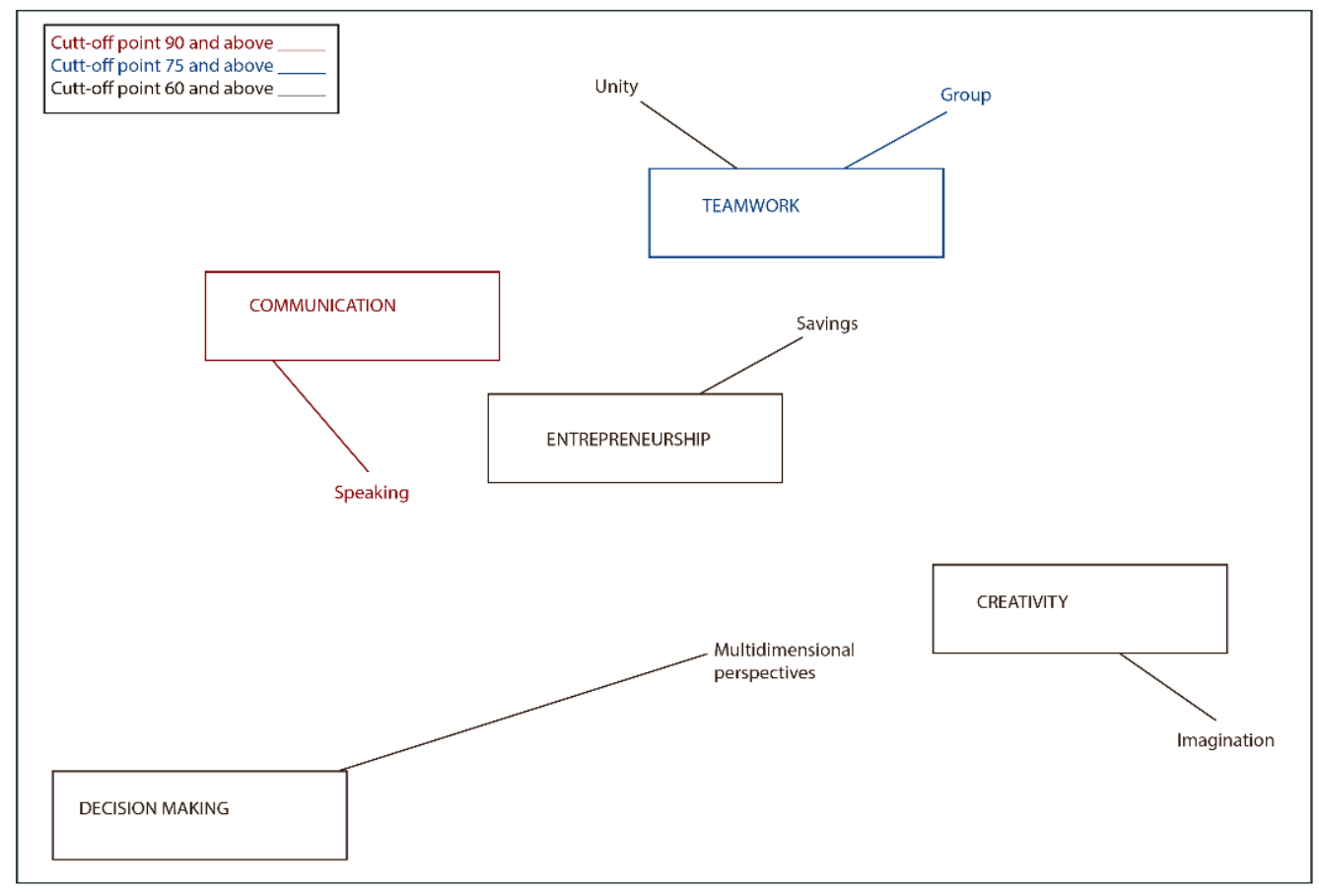

Figure 4 The concept network created for breakpoint 60 and above 
thinking, and problem-solving. Also, the concepts of analytical thinking and creativity were directly associated with pre-service science teachers. It was seen that the concept of decision making was associated with selfconfidence, generating an idea, reasoning, problem-solving words. Generating an idea is associated with both the concepts of decision making and entrepreneurship. In addition to that, it was seen that the reasoning word was associated with both the concepts of decision making and creativity.

The findings obtained from the "related sentence" part of WAT are presented below. Frequencies of the sentences and sample sentences are shown in Table 1. The scientifically correct sentence frequencies $f=67, f=44, f$ $=44, \mathrm{f}=72, \mathrm{f}=35$, respectively, related to the concepts of Communication, creative thinking, entrepreneurship, teamwork, decision making, and analytical thinking are also given. In addition to this, it is seen that the most scientific sentence about the concept of teamwork has been created. Examples of this situation are presented below:

C: Communication skill enables us to transfer emotions, thoughts, gestures, and mimics with people and transfer emotions to solve problems (3 PT-26).

Cr: A person with creative thinking creates new things using his imagination from a different perspective (3PT-27).

$\boldsymbol{E}$ : People with entrepreneurship skills are self-confident, risk-taking, living for success, sensing the possibilities, and speaking without excitement in front of society (3PT-11).

T: Teamwork develops behaviors such as cooperation, collaboration, and Communication (4PT-25).

D: People with advanced skills are logical people who can think analytically, make predictions and estimates correctly, make due diligence, draw conclusions from events, and accept responsibility (3PT-11).

A: In analytical thinking, we should conduct our research by establishing the cause-effect relationship of the events and taking into account the most refined details (1PT-25).

The frequencies of the concepts of communication, creative thinking, entrepreneurship, teamwork, decision making and analytical thinking with non-scientific or superficial information have $\mathrm{f}=80, \mathrm{f}=101, \mathrm{f}=98, \mathrm{f}=68$, $f=106, f=88$, respectively. It is understood that preservice science teachers write sentences that are not scientifically correct and contain superficial information for the most decision-making and the least teamwork concepts. Some of the sentences of the related concepts are given below:

C: Communicating with people improves self-confidence (2PT-42).

Cr: Creative thinking shows bow wide a person looks (4PT 4).

$\boldsymbol{E}:$ To be an entrepreneur, a person needs a particular infrastructure (2PT-16).

T: Group work is to divide labor (2PT-10).

D: Decision making is a worrying and challenging selection process (1PT-9).

A: Analytical thinking is directly proportional to creativity (1PT20).

From the findings obtained from the research, it was determined that there were no misconceptions related to the concepts of Communication, creativity, entrepreneurship, teamwork, decision making, and analytical thinking.

When the findings related to communication skills, which is one of the life skills, are examined, it is seen that almost all of the pre-service science teachers associate Communication with only the speaking word (Figure 2). The fact that pre-service science teachers only emphasize the concept of speaking can indicate that pre-service teachers' opinions about Communication are limited. Because basically, when the definition of the concept of Communication is examined; it is the creation and coding of any message to be delivered by the sender, the transmission of the message via the channel, the transmission, perception, and feedback of the message by the sender (Gökçe, 2003). In the simplest terms, Communication is an effort to convey the message (Castells, 2009; Güven, 2013). It is seen that none of the pre-service science teachers emphasized these concepts. As seen in Figure 5, unlike the previous breakpoint point in this range, the pre-service teachers are associated with gesture-mimic and diction words. When the breakpoint is flexed by a unit, the concept of Communication has been associated with language, listening, and human words.

In the literature on Communication, skill is defined as "being able to listen and react effectively based on respect and empathy", "being able to open himself/herself properly by speaking in concrete", "being able to convey

Table 1 Sentences and frequencies related to concepts

\begin{tabular}{llll} 
Life Skills & $\begin{array}{l}\text { Scientifically Correct } \\
\text { Sentences Related to the } \\
\text { Concept }\end{array}$ & $\begin{array}{l}\text { Sentences Containing } \\
\text { Unscientific or Superficial } \\
\text { Information }\end{array}$ & $\begin{array}{l}\text { Intentionally Left } \\
\text { Blank }\end{array}$ \\
\hline Communication & $67(40.6 \%)$ & $80(48.5 \%)$ & $18(10.9 \%)$ \\
Creativity & $44(26.7 \%)$ & $101(61.2 \%)$ & $20(12.1 \%)$ \\
Entrepreneurship & $44(26.7 \%)$ & $98(59.4 \%)$ & $23(13.9 \%)$ \\
Teamwork & $72(43.6 \%)$ & $68(41.2 \%)$ & $25(15.2 \%)$ \\
Decision Making & $35(21.2 \%)$ & $106(64.2 \%)$ & $24(14.6 \%)$ \\
Analytical Thinking & $41(24.9 \%)$ & $88(53.3 \%)$ & $36(21.8 \%)$ \\
Total & 303 & 541 & 144 \\
\hline
\end{tabular}

C: Communication, Cr: Creativity, E: Entrepreneurship, T: Teamwork, D: Decision making, A: Analytical Thinking 


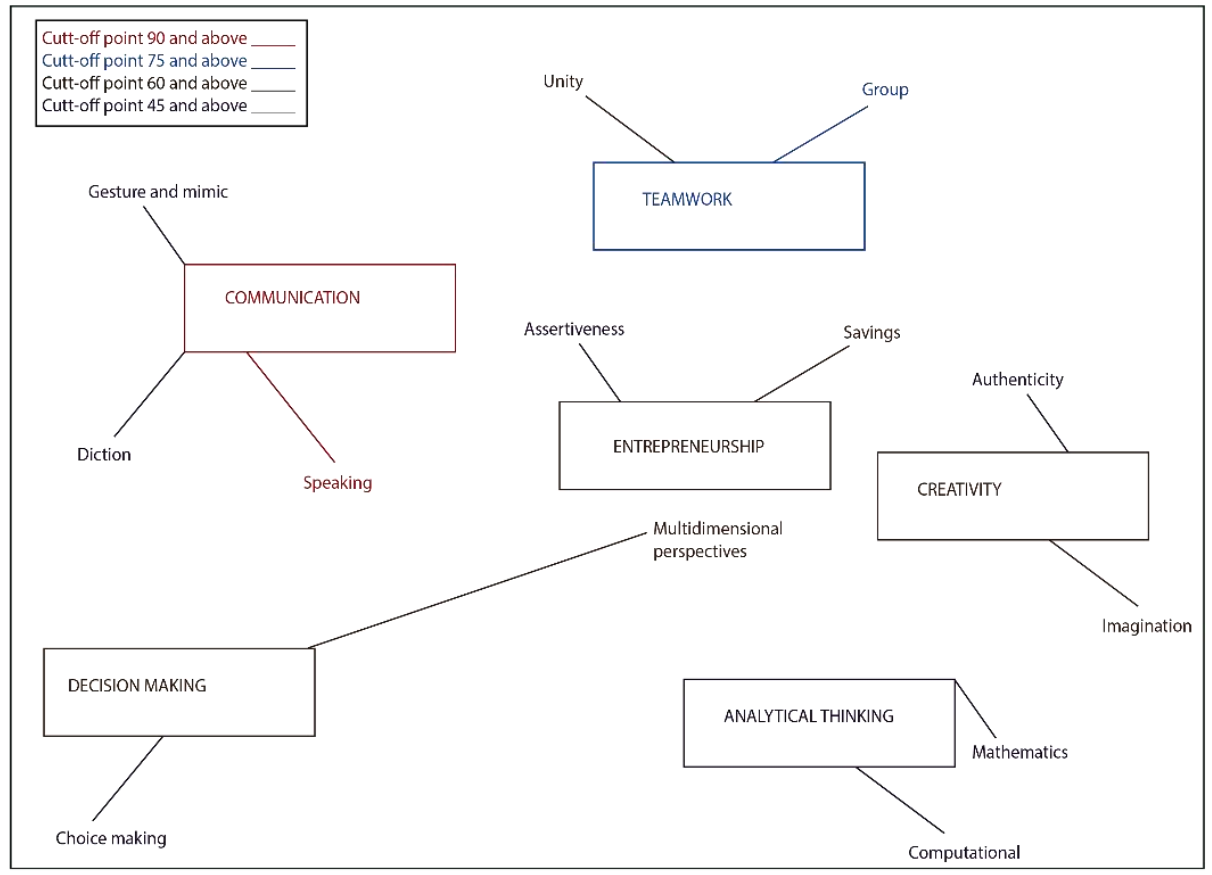

Figure 5 The concept network created for breakpoint 45 and above

her/his feelings and thoughts in me-language without wearing a mask in front of someone ", "being able to protect his rights without belittling others", "being able to use verbal messages and non-verbal messages in harmony" and "learned behaviors that enable the individual to establish satisfactory relationships with others, bring positive reactions from others and make the individual easier to live in a society" (Baker \& Shaw, 1987; McWhirter \& Voltan-Acar, 1985; Sahin, 2010). On the other hand, pre-service science teachers made the least sociability, telephone, eye contact, the style, respect, conversation, agreement, expression of oneself, and body language words related to the concept of Communication. However, communication skill has some indicators such as "making eye contact, respecting, self-expression, acting empathically, being an effective listener, opening up appropriately, assertive behaviors, acting transparent, concrete speaking" (Kirman-Bilgin, 2019). When the connections of the concept are analyzed, it is seen that none of the crucial indicators such as assertive behaviors, concrete speaking, and being transparent are emphasizing. It is also noteworthy that less than 15 people have associated essential indicators such as expression of oneself, body language, and eye contact. Although the number of words produced with communication skills is higher than other skills, it can be said that the knowledge of pre-service science teachers about communication skills is partially sufficient, and they do not know enough the communication skill. Pre-service science teachers did not take enough courses for Communication and its indicators during their undergraduate education period may have been significant in not knowing about communication skills as learning is a process and requires knowledge about the subject (Alaca, 2019). When the data obtained from the research are evaluated, this research's results are in parallel with the Alaca (2019) study results towards pre-service science teachers' communication skills.

According to the findings obtained from teamwork, they mostly associated the concept of teamwork with the group word (Figure 3). When the breakpoint was flexed by one unit, it was seen that teamwork was associated with the word "unity". When the literature is examined, teamwork is when individuals who establish effective relationships with each other come together and carry out in solidarity (Kocabaş \& Gökbaş, 2003; Robinson \& Zajicek, 2005). In other words, in line with the goals determined as a team, it was defined as joint studies of each team member to fulfill the responsibilities in cooperation by giving up their individual goals (Ergin, 2000). Therefore, the pre-service science teachers' group and collaboration associations are essential for teamwork and overlap with the literature's definitions. Teamwork has some indicators such as "being fair, having consciousness about the given task, feeling of belonging to the group, fulfilling the responsibility, sharing their ideas appropriately, evaluating the different ideas that arise in terms of the desired features, realizing what the teamwork has brought to itself" (Kirman-Bilgin, 2019). They also linked teamwork with the word solidarity. Although this answer is correct, they did not use any expression that includes justice, a sense of belonging, opening their ideas appropriately, and realizing their winnings. It is also remarkable that less than 15 pre-service teachers emphasized their essential expressions such as friendship, project, division of labor, adjustment, and sense 


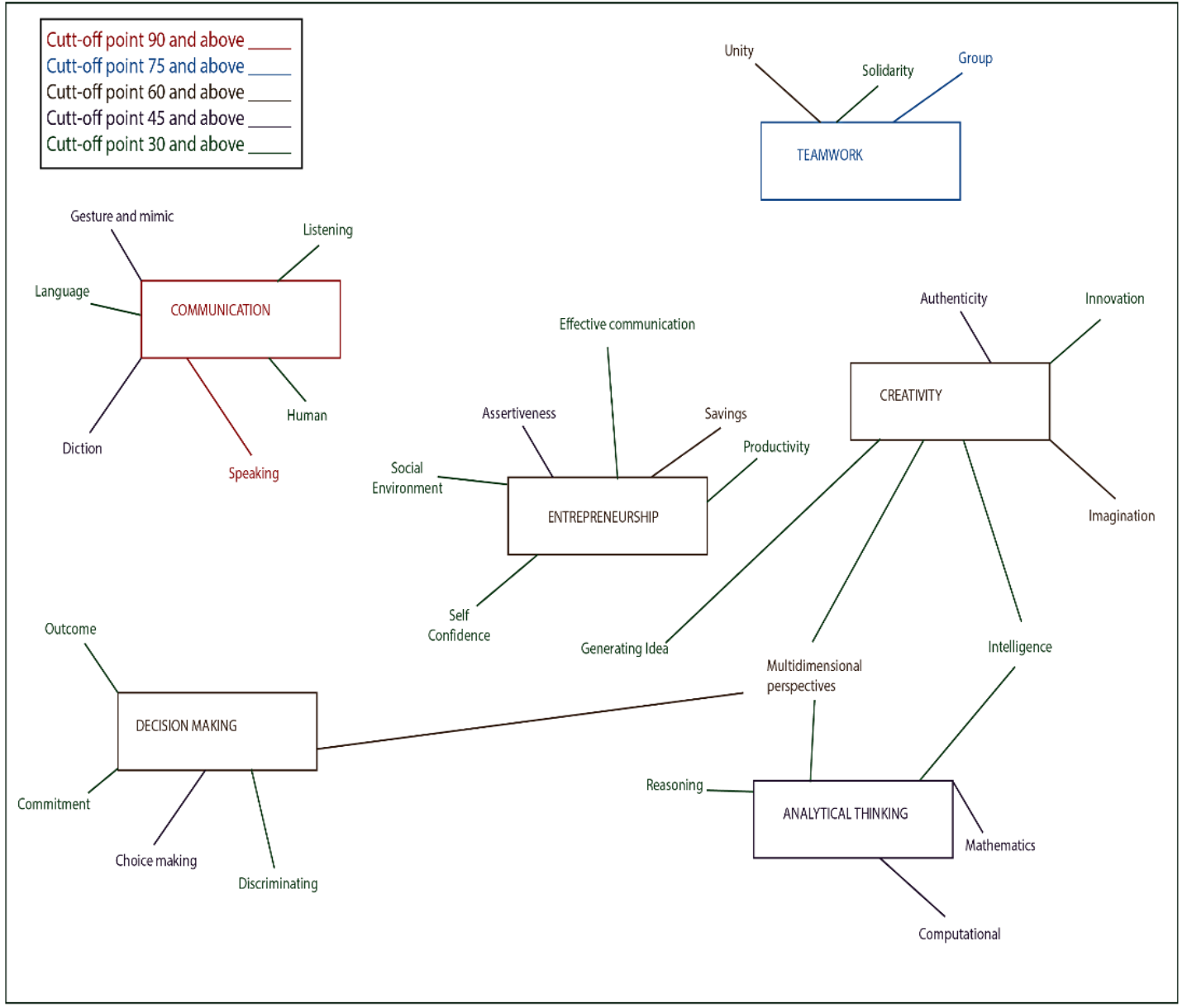

Figure 6 The concept network created for breakpoint 30 and above

of responsibility. Considering the definitions made and the indicators of teamwork, it can be said that taking responsibility, division of labor, and being compatible are fundamental concepts for teamwork. However, considering the frequencies of the number of pre-service teachers emphasizing these words, it can be said that they do not have a good command of teamwork. This result may be because pre-service teachers are not adequately involved in teamwork tasks as the team spirit can only be understood within such tasks.

Nevertheless, it can be said that pre-service science teachers' perceptions and associations regarding teamwork are partially sufficient. Güçlü \& Okçu (2015) concluded that their perceptions of primary school teachers towards teamwork were moderately sufficient. The result of the research is in parallel with this research.

It was determined from the findings obtained from entrepreneurship, which is one of the life skills, that the pre-service science teachers could not produce enough words about this skill. When the words are examined, it is seen that the concept of entrepreneurship is mostly associated with the word savings. The fact that they associate the concept of entrepreneurship with the most savings can be a preliminary indicator of pre-service teachers' business establishment in their minds. The concept of entrepreneurship is associated with assertiveness when a unit flexes a breakpoint. Entrepreneurship and assertiveness are two closely related concepts (Kirman-Bilgin, 2019). An individual who will attempt to start a business should also have assertive behaviors to evaluate the opportunities better. When the other words were examined, it was seen that they produced effective Communication, social environment, selfconfidence, and productivity.

On the other hand, the least stated words with entrepreneurship are related to profession, ability, and businessman. Entrepreneurship skills are listed in the literature by Lambing \& Kuehl (2000) as tolerance to disabilities, perseverance, trust, determination, risk management, a positive attitude towards change, tolerance of uncertainties, need to achieve, alertness, creativity, and understanding of the big picture. Although the words were given by the pre-service science teachers partially overlap with the literature, it is remarkable that especially the risk concept has not been emphasized by any of them. There are some indicators about entrepreneurship: "developing business ideas, emphasizing that the business idea is different from other business ideas, determining short- 


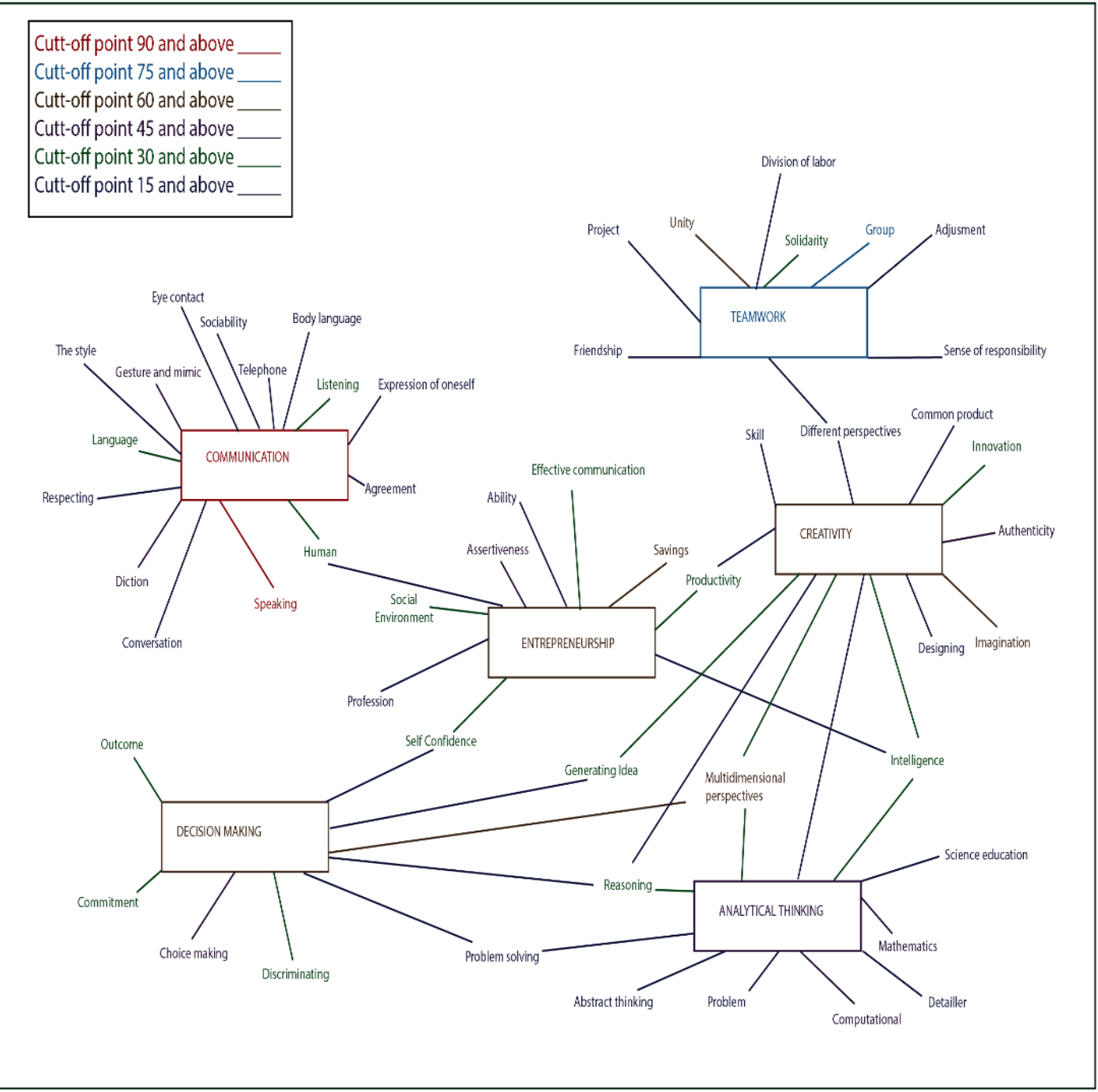

Figure 7 The concept network created for breakpoint 15 and above

term goals, setting the market share target, identifying potential customers, conducting competitor analysis, determining transportation channels to the customer, drawing a workflow diagram, determining the duties and responsibilities of the staff, calculating the income and expenses of his business, calculating the profit of the business, marketing the product" (Kirman-Bilgin, 2019). The words containing these indicators are not highlighted, maybe because pre-service science teachers do not have sufficient knowledge of entrepreneurship skills. As the brain connotation of pre-service science teachers about entrepreneurship is very limited. This condition may result from that no professional course related to entrepreneurship has been taken or that entrepreneurship practices are not sufficiently included in the courses. Undoubtedly, schools are one of the most effective environments for acquiring life skills. In the related literature, it is possible to come across studies in which science course curriculum achievements are discussed from different perspectives. For example, Deveci \& Çepni
(2017) investigated the 2013 elementary science course curriculum in terms of entrepreneurial skills. As a result, they stated that while communication and creativity skills were encountered the most, risk-taking, using time effectively, and teamwork skills were never encountered. Politis (2005) emphasizes that entrepreneurship learning is an applied process developed by experiencing, reflecting, thinking, and acting in knowledge. Therefore, it is vital to include practices involving entrepreneurship in learning environments to gain this skill.

According to the findings on the concept of creativity, it was mostly associated with the word imagination. When a unit flexes the breakpoint, it has been observed that it is associated with authenticity. Unlike the previous one, it is associated with innovation, generating ideas, multidimensional perspectives, and intelligence. Creative thinking skill has some indicators such as "producing new ideas scientifically, technologically, and socio-culturally" (Kirman-Bilgin, 2019). According to Adair (2007), he thinks creatively, not always suggesting a new idea, but 
combines existing ideas or elements. However, the common point of many definitions about creativity in the literature is based on the emergence of a suitable, original, and new idea or product (Atkinson, 2000; Conklin, 2001; Piirto, 1992). Therefore, considering the indicators of creativity and the definitions made in the literature, it can be said that the connotations formed in the minds of preservice science teachers overlap with the literature.

According to the findings obtained about decision making, pre-service science teachers mostly associated their decision-making skills with multidimensional perspectives. When a unit flexes a breakpoint, it is seen that they relate it to choice making. Decision making is defined in the literature as "the individual has possible solutions and chooses the most suitable solution among them" (Kuzgun, 2000; Mettas, 2011). According to another definition, "obtaining the desired results of the situation encountered, researching some information, creating logical solutions with reasoning, and choosing the most appropriate solution (Sağır, 2006). These definitions in the literature support the dominant words in the minds of pre-service science teachers. Unlike the previous ones, they associated the concept of decision making with the words outcome, commitment, and discrimination at the next breakpoint.

On the other hand, when we look at the concept network, pre-service teachers' words are least evident in their minds when it comes to self-confidence, generating ideas, reasoning, and problem-solving. "Expressing/feeling a problem situation faced in daily life, expressing why the problem to be solved, researching solutions for the problem, sorting the positive and negative aspects of the solutions, comparing the solutions and requests, determining and applying the appropriate solution" is some decision making indicators (Kirman-Bilgin, 2019). One of the skills in which familiar words, which are defined as roofs, is associated with decision making. Therefore, it can be said that the connotations formed in the minds of preservice science teachers for decision-making skills overlap with the literature, although they relate the words "reasoning, problem-solving" with the minimum.

Analytical thinking skill was mostly associated with computational and mathematic words. When a unit flexes a breakpoint, it is seen that analytical thinking skill is associated with reasoning, multidimensional perspectives, and intelligence words. According to Sternberg \& Collaborator (2006), analytical thinking includes the skills used to analyze, evaluate, judge, or compare similarities and differences. Moving from this point, Dewey (2007) defined analytical thinking as examining the parts separately that make up the objects, then examining how the parts interact with each other to ensure the system's process. When the definitions in the literature are examined, it can be said that the prevailing words in the minds of pre-service science teachers partially coincide with the definitions.
On the other hand, analytical thinking has some indicators such as "editing the data to solve the problem faced, analyzing the problem by establishing a relationship between the data, solving the problem by classifying, analyzing the problem by generalizing, solving the problem by making error analysis and analyzing the problem by customizing it" (Kirman-Bilgin, 2019). It is remarkable that the words "solving/analyzing, being detailed", which are important for analytical thinking, are emphasized by less than 15 pre-service science teachers, and that no one emphasizes "classification" and "generalization". This situation may be related to their lack of mastery of analytical thinking skills. The fact that the total number of words produced related to analytical thinking skill is less than other skills supports this situation. To summarize, not taking any courses not only for analytical thinking skills but also for other life skills may have negatively affected preservice science teachers' knowledge of this skill. Researches show that, with updating the curriculum, teachers do not develop themselves in line with the knowledge and skills requested from them (Kelly, 2000). When the updated science education undergraduate program is analyzed, it is seen that the "critical and analytical thinking" course is among the elective courses of teaching profession courses. However, this research shows that pre-service science teachers' knowledge about analytical thinking skills is quite limited. One of the reasons for this situation may be that, although the programs are updated, the undergraduate course contents are not sufficiently structured or implemented within these changes' framework.

One of the second sub-objectives of the research is to determine pre-service science teachers' conceptual knowledge status. For this reason, they were asked to form a sentence related to Communication, creative thinking, entrepreneurship, teamwork, decision making, and analytical thinking, which are life skills. Thus, the concept formation that supports the establishment of links between the concepts or the misconceptions that limit the links were determined. It is seen that pre-service science teachers produce the most scientific and correct sentences about teamwork. Teamwork is linked to many skills. Collaborative learning, including teamwork, enables group members to take an active role in activities and to recognize unnoticed problems (Johnson \& Johnson, 2005; Şimşek, Doymuş, \& Bayrakçeken, 2004; Yeşilyurt, 2010). Preservice science teachers' experiences in teamwork in which they take part in the educational process may have facilitated scientific sentences. When the related table (Table 1) is examined, it is seen that scientific and correct sentences are produced regarding the least decision-making skill. Considering the relationships seen in the concept network, few words related to decision making skill support this situation. It can be said that decision making skill is a skill that can develop better with guidance. Accordingly, the fact that pre-service science teachers are 
not supported sufficiently in decision-making processes may have hurt this skill's internalization. Patronis, Potari \& Spiliotopoulou (1999), in their study, have concluded that they can make better decisions with the guidance. On the other hand, when the concept network for word association is analyzed, it is noteworthy that teamwork is the skill where the scientifically correct sentences with the highest rate are established, although the skill they associate with at least word is teamwork. Also, any misconception about pre-service science teachers' life skills was not detected.

\section{CONCLUSION}

As a result of the research, it was determined that preservice science teachers could not produce enough answer words about related life skills. It was revealed that the number of pre-service teachers who responded significantly about analytical thinking skills was quite limited. This situation shows those pre-service science teachers' inadequate cognitive structures about life skills. Besides, it was determined that pre-service science teachers could not match their life skills closely related to each other. Only a creative thinking skill was directly associated with analytical thinking skills. This situation shows that preservice teachers' supporting and complementary features in their minds that constitute life skills are not fully understood.

Depending on the results of this research, the following suggestions can be made;

When the importance of life skills is considered in daily life and professional life, teachers need to have these skills and bring them to their students. Therefore, elective undergraduate courses that allow them to recognize and internalize these skills can be introduced, or the number of these courses can be increased.

Enriching the existing undergraduate course content with the applications and providing undergraduate course content containing life skills can be attractive for preservice teachers.

\section{REFERENCES}

Abell, S. K. (2008). Twenty years later: Does pedagogical content knowledge remain a useful idea?. International Journal of Science Education, 30(10), 1405-1416.

Adair, J. (2007). The art of creativet hinking: How to develop your powers of innovation and creativity. Philadelphia: Kogan Page Publishers.

Alaca, M. B. (2019). Fen bilimleri öğretmen adaylarının iletişim becerisi ile ilgili mesleki bilgilerinin ve bu beceriyi kullanma durumlarının belirlenmesi [Determination of the pre-service science teachers professional knowledge related to their communication skill and use of this skill] [Unpublished master's thesis]. Trabzon University (In Turkish).

Atkinson, S. (2000). Does the need for high levels of performance curtail the development of creativity in design and technology project work?. International Journal of Technology and Design Education, 10(3), 255-281.

Bahar, M., \& Özatl, N.S. (2003). Examining the cognitive structure of 9th class students in the subject of basic components of living through word associate test. Balkesir Üniversitesi Fen Bilimleri Dergisi, 5(1), 134-141.
Bahar, M., Johnstone, A. H., \& Sutcliffe, R. G. (1999). Investigation of students' cognitive structure in elementary genetics through word association tests. Journal of Biological Education, 33(3), 134-141.

Bahar, M., Nartgün, Z., Durmuș, S., \& Bıçak, B. (2006). Geleneksel ve alternatif ölçme ve değerlendirme ögretmen el kitabr [Traditional-alternative: Measurement and evaluation handbook for teachers]. Ankara: PegemA Publishing.

Baker, S. B., \& Shaw, M. C. (1987). Improving counseling through primary prevention. Ohio: Merrill Publishing Company.

Baykara-Pehlivan, K. (2005). A study on perception of communication skills of pre-service teachers. Elementary Education Online, 4(2), 1723.

Brown, N., Morehead, P., \& Smith, J. B. (2008). But I love children: Changing elementary teacher candidates' conceptions of the qualities of effective teachers. Teacher Education Quarterly, 35(1), 169-183.

Burbules, N. C., \& Linn, M. C. (1991). Science education and philosophy of science: congruence or contradiction?. International Journal of Science Education, 13(3), 227-241.

Castells, M. (2009). Communication power. Oxford: Oxford University Press.

Conklin, W. (2011). Higher-order thinking skills to develop 21st century learners. Huntington Beach: Shell Education Publishing.

Crespo, M. Á. G., \& Pozo, J. I. (2004). Relationships between everyday knowledge and scientific knowledge: Understanding how matter changes. International Journal of Science Education, 26(11), 1325-1343.

Deveci, I.., \& Çepni, S. (2017). Examination of science education curriculum (5-8 grades) in terms of entrepreneurial characteristics. Alan Eğitimi Arastırmalar Dergisi, 3(2), 52-74.

Dewey, R. A. (2007). Psychology: an introduction. http:///www.intropsych.com/ch04_senses/whole_is_other_than _the_sum_of_the_parts. html.

Erbil, O., Demirezen, S., Erdoğan, A., Terzi, U., Eroğlu, H., \& İbis, M. (2004). Öğrenci merkezli eğitim uygulama modeli [Studentcentered education application model]. İmir İktisat Kongresi Eğitimde Uygulamalar Bolumu Tebligí, www. egitek. meb. gov. tr/EgitekHaber.

Ercan, F., Taşdere, A., \& Ercan, N. (2010). Observation of cognitive structure and conceptual change through word association test. Journal of Turkish Science Education, 7(2), 136-154.

Ergin, A. (2000). Takım temelli örgütlerde performans değerleme sistemleri. Master thesis, Marmara University, İstanbul.

Gilbert, J. K. (2006). On the nature of "context" in chemical education. International Journal of Science Education, 28(9), 957-976.

Gökçe, O. (2003). İletisim bilimine giriș: Insanlar arast ilişkilerin sosyolojik bir analizi [Introduction to communication science: $A$ sociological analysis of interpersonal relationships]. Ankara: Turhan Bookstore.

Güçlü, N., \& Okçu, V. (2015). Relation between perceptions of primary school teachers related to effective team work and their organizational commitments. Yuzuncu Yil University Journal of Education, 12(1), 49-69.

Gürkan, B. (2019). Primary school teacher candidates' cognitive structures in relation to curriculum, instruction, instruction planning and evaluating instruction. Kastamonu Education Journal, 27(2), 633-645.

Güven, B. (2013). Etkili iletișim [Effective communication]. Ankara: Pegem Publishing.

İnel, Y., Akar, C., \& Uztemur, S. (2016). 8th students' perceptions towards administration types: Revealing their cognitive structures via word association test. Journal of History School, 9(XXVIII), 523540.

Johnson, D. W., \& Johnson, R. T. (2005). Co-operative Learning, R. M. Gillies and A. F. Ashman (Ed.), Student Motivation in Cooperative Groups, Social Interdependence Theory, London and New York, Taylor and Francis e-Library.

Karasar, N. (2012). Bilimsel arastrma yöntemi [Scientific research method]. Ankara: Nobel Publishing (In Turkish). 
Kaya, M. F., \& Taşdere, A. (2016). An alternative measurement and assessment method for elementary Turkish education: Word Association Test (WAT). Electronic Turkish Studies, 11(9), 803-820.

Kelly, J. (2000). Rethinking the elementary science methods course: A case for content, pedagogy and informal science education. International Journal of Science Education, 22(7), 755-777.

Kind, V. (2009). A conflict in yourhead: An exploration of trainee science teachers' subject matter knowledge development and its impact on teacher self-confidence. International Journal of Science Education, 31(11), 1529-1562.

Kirman-Bilgin, A. (2019). Fen bilimlerinde yaşam becerileri eğitimi [Life skills education in science]. Ankara: Pegem Publishing (In Turkish).

Kocabaş, İ., \& Gökbaş, M. (2003). Team working in education. Education and Science, 28(130), 8-15.

Kolburan, G., \& Tosun, Ü. (2011). İlkögrretim ikinci kademe ögrrencileri arasinda yaşam becerileri eğitimi yoluyla I. kademede edinilmis değerleri pekistiren gelisimsel bir model önerisi [Proposal for a developmental model that reinforces the values acquired in the first grade through life skills education among the second grade primary school students]. Değerler eğitimi sempozyumu-sosyal ve kurumsal yönleriyle değerler eğitimi, bildiri özetleri, (s.246- 247). Eskişehir Osmangazi Üniversitesi (In Turkish).

Kuzgun, Y. (2000). Meslek danısmanliğ kuramlar uygulamalar [Vocational counseling theories applications]. Ankara: Nobel Publishing (In Turkish).

Lambing, P., \& Kuehl, C. R. (2000). Entrepreneurship. Upper Saddle River: Prentice Hall.

McWhirter, J., \& Voltan-Acar, N. (1985). Cocukla iletisim CCommunication with the child. Ankara: Nüve Printing Press

Mettas, A. (2011). The development of decision-making skills. Eurasia Journal of Mathematics, Science and Technology Education, 7(1), 63-73.

Ministry of National Education [MoNE] (2018). İlkögrretim kurumlar (ilkokullar ve ortaokullar) fen bilimleri dersi ögretim programı. Ankara: MEB Publication.

Nartgün, Z. (2006). Fen ve teknoloji öğretiminde ölçme ve değerlendirme Measurement and evaluation in science and technology education7. M. Bahar (Eds.) Fen ve Teknoloji Ögrretimi (s.355-415), Ankara: PegemA Publishing (In Turkish).

Nilsson, P. (2008). Teaching for understanding: The complex nature of pedagogical content knowledge in pre-service education. International Journal of Science Education, 30(10), 12811299.

Padilla, K., Ponce-de-León, A. M., Rembado, F. M., \& Garritz, A. (2008). Undergraduate professors' pedagogical content knowledge: The case of 'amount of substance'. International Journal of Science Education, 30(10), 1389-1404.

Patronis, T., Potari, D., \& Spiliotopoulou, V. (1999) Students' argumentation in decision-making on a socio-scientific issue: Implications for teaching. International Journal of Science Education, 21(7), 745-754.

Piirto, J. (1998). Understanding those who create. Dayton, OH: Ohio Psychological Press.

Politis, D. (2005). The process of entrepreneurial learning: A conceptual framework. Entrepreneurship Theory and Practice, 29(4), 399-424.

Robinson, C. W., \& Zajicek, J. M. (2005). Growing minds: The effects of a one-year school garden program on six constructs of life skills of elementary school children. HortTechnology, 15(3), 453-457.

Ross, J. A. (1992). Teacher efficacy and the effects of coaching on student achievement. Canadian Journal of Education, 17(1), 51-65.

Sağır, C. (2006). Karar verme sürecini etkileyen faktörler ve karar verme sürecinde etiğin önemi: Uygulamal bir araştırma [Factors affecting decision making process and importance of the ethics in decision making process: An empirical research] [Unpublished master's thesis]. Trakya University.

Şahin, Y. (2010). İletişim becerilerine genel bir bakış [An overview of communication skills]. A. Kaya (Eds.), Kisiler arast iliskiler ve etkili iletişim içinde (s. 32-53). Ankara: Pegem Publishing.

Simon, J.L., \& Burstein, P. (1985). Some principles of measurement. New York: Random House.
Simşek, Ü., Doymus, K., \& Bayrakçeken, S. (2004). Lise Düzeyinde Öğrenim Gören Öğrencilere Grupla Öğrenme Metodunun Kazandırdığ1 Bilgi ve Beceriler, XIII. Ulusal Eğitim Bilimleri Kurultayı, Malatya, 6-9 Temmuz, İÜ. Eğitim Fakültesi.

Sternberg, R. J., \& Rainbow Project Collaborators. (2006). The Rainbow Project: Enhancing the SAT through assessments of analytical, practical, and creative skills. Intelligence, 34(4), 321-350.

Stolk, M. J., Bulte, A. M., de Jong, O., \& Pilot, A. (2009). Towards a framework for a professional development programme: Empowering teachers for context-based chemistry education. Chemistry Education Research and Practice, 10(2), 164-175.

Stronge, J. H., \& Hindman, J. L. (2003). Hiring the best teachers. Educational Leadership, 60(8), 48-52.

Stronge, J. H., Ward, T. J., Tucker, P. D., \& Hindman, J. L. (2007). What is the relationship between teacher quality and student achievement? An exploratory study. Journal of Personal Evaluation in Education, 20(3-4), 165-184.

World Health Organization. (1999). Partners in life skills education. Geneva, Switzerland: World Health Organization, Department of Mental Health.

Yeşilyurt, E. (2010). Evaluation of the suitability of teacher candidates' qualities to cooperative learning method. Dicle University Journal of Ziya Gökalp Education Faculty, (14), 25-37. 